\title{
Long-term effects of prenatal oestrogen treatment on genital morphology and reproductive function in the rat
}

\author{
B. Vannier and J. P. Raynaud \\ Centre de Recherches Roussel Uclaf, 93230 Romainville, France
}

\begin{abstract}
Summary. Prenatal exposure to RU 2858 (11 $\beta$-methoxy-19-nor-17 $\alpha$-pregna1,3,5(10)-trien-20-yne-3,17-diol) alters the genital tract of rat offspring more markedly than does oestradiol which is bound to a specific plasma protein. The morphological changes observed in the male fetus are partly restored during infancy and maturity. The main effect of the treatment is seen in the female offspring and consists of alterations of the genital tract and of reproductive function.
\end{abstract}

\section{Introduction}

Numerous studies on the action and mechanism of perinatal oestrogen treatment in the rat have been reported, many of which are concerned with effects on sexual behaviour after oestrogen administration to the newborn (Whalen \& Nadler, 1963; Gorski, 1963; Levine \& Mullins, 1964; Harris \& Levine, 1965; Barraclough, 1968; Passouant-Fontaine \& Flandre, 1969; Dorner, Docke \& Hinz, 1971; Brown-Grant, 1974; Brown-Grant, Fink, Greig \& Murray, 1975; Hendricks \& Weltin, 1976), whilst others describe the anatomical modifications of the genital tract of the fetus after treatment of mothers during embryonic sexual differentiation (Greene, Burrill \& Ivy, 1940; Marois, 1968). In the present study we have investigated the effects of oestrogen treatment of mothers on the genital morphology of the rat fetus at term and of infant and adult offspring, and examined the consequences of treatment on reproductive function. The activity of the synthetic oestrogen, RU 2858 (moxestrol), was compared to that of oestradiol. Previous experiments with the rat have already suggested that RU 2858 is a potent oestrogen as regards its action on the fetus (Vannier \& Raynaud, 1975; Raynaud, Bouton, Philibert \& Vannier, 1976) and on the newborn (Doughty, Booth, McDonald \& Parrott, 1975). Its activity can be explained by the fact that, unlike oestradiol, it is not bound by plasma oestradiol-binding protein (Raynaud, 1973) but forms a more stable complex than oestradiol with the cytoplasmic oestrogen receptor (Bouton \& Raynaud, 1979).

\section{Materials and Methods}

\section{Animals and treatment}

Sprague-Dawley SPF rats (200 g) supplied by IFFA CREDO (France) were mated. The animals were given food and water ad libitum and maintained in air-conditioned surroundings under controlled lighting conditions. Pregnant females were placed in individual cages and treated with RU 2858 (11 $\beta$-methoxy-19-nor-17 $\alpha$-pregna-1,3,5(10)-trien-20-yne-3,17-diol) or oestradiol. The compounds were given subcutaneously in $0.5 \mathrm{ml}$ of a $5 \%$ solution of benzyl alcohol in sesame oil from Days 16 to 20 of gestation, Day 1 being determined by the presence 
of spermatozoa in the vaginal smears. The daily doses administered were $0 \cdot 4,2,10$ or $50 \mu \mathrm{g} \mathrm{R}$ $2858 /$ rat and 50,250 or $1250 \mu \mathrm{g}$ oestradiol/rat. The control group was given solvent alone in the same conditions.

\section{Examination of the fetuses and young}

Some of the pregnant females were killed on the day before term (i.e. Day 22). At autopsy, fetal wastage was determined and fetuses were excised, scored, weighed, and sexed by examination of the gonads in situ. The abdominal region of some male and female fetuses was embedded in paraffin wax, transversally sectioned at $6 \mu \mathrm{m}$ and every 5 th section was stained with haematoxylin and eosin for histological examination.

The remaining pregnant females were allowed to litter. The date of parturition was noted and growth of the young was evaluated by regular recording of bodyweight. At 2, 4 and 8 weeks of age, a random sample of male offspring from mothers given medium doses was killed for histological examination of serial transverse sections of the urogenital sinus. Prostate growth was measured by the distance between the proximal and distal appearance of the gland regardless of its position round the urethra. At 12 weeks of age, male and female young from mothers in all dose groups were killed for macroscopic examination of the genital tracts. In the male offspring, variations in the development of the prostate and seminal vesicles were evaluated by comparison with organs from control animals.

\section{Study of genital development and reproductive function}

The surviving 3-month-old animals from treated mothers were mated with adult rats from untreated mothers. After 2 weeks of cohabitation daily vaginal smears were taken from nonpregnant females for 15 days to record oestrous cycles; the animals were then killed for examination of the genital tract. The pregnant females were killed on Day 22 of gestation. Mating rate (percentage of females with spermatozoa), fecundity rate (percentage of pregnant females) and fertility (number of implantation sites) were determined and compared to those of the control group.

\section{Results}

In the pregnant females autopsied just before term a high incidence of fetal wastage was noted for doses of $\geq 2 \mu \mathrm{g}$ RU 2858 and $50 \mu \mathrm{g}$ oestradiol which increased dose-dependently (Table 1). Oestrogen treatment also resulted in significantly underweight live fetuses. In the pregnant females allowed to go to term, the gestation lengths were comparable in all but the highest-dose groups. In these groups the mean number of expelled young was decreased, particularly after oestradiol treatment. Moreover, in both these groups many of the young were found dead on the day of birth, but it was not possible to establish whether they died before or after birth. Survival rate at 9 weeks of age was low (Table 1). Females which did not give birth were killed and dead fetuses and traces of expulsion were seen in the uteri.

In the low-dose groups, the bodyweight of the young increased normally, whereas the growth of male and female offspring from mothers given $50 \mu \mathrm{g}$ RU 2858 or $1250 \mu \mathrm{g}$ oestradiol was retarded compared to that of controls. This difference persisted for at least 9 weeks. 
Table 1. Observations on rats allowed to litter or killed after oestrogen treatment during gestation (Days 16-20)

\begin{tabular}{|c|c|c|c|c|c|c|c|c|c|}
\hline \multirow[b]{3}{*}{$\begin{array}{l}\text { Treatment } \\
\text { and dose } \\
\text { ( } \mu \mathrm{g} / \mathrm{rat} / \text { day) }\end{array}$} & \multirow[b]{3}{*}{$\begin{array}{c}\text { Fetal } \\
\text { wastage } \\
\text { on } \\
\text { Day 22 } \\
(\%)^{\dagger}\end{array}$} & \multicolumn{6}{|c|}{ Parturitions } & \multirow{2}{*}{\multicolumn{2}{|c|}{ No recorded parturitions }} \\
\hline & & & \multicolumn{5}{|c|}{ Offspring } & & \\
\hline & & $\begin{array}{l}\text { No. of } \\
\text { females }\end{array}$ & $\begin{array}{c}\text { Mean } \\
\pm \text { s.e.m. } \\
\text { gestation } \\
\text { (days) }\end{array}$ & $\begin{array}{c}\text { Mean } \\
\pm \text { s.e.m. } \\
\text { no./litter }\end{array}$ & $\begin{array}{l}\text { No. } \\
\text { alive }\end{array}$ & $\begin{array}{l}\text { No. } \\
\text { dead }\end{array}$ & $\begin{array}{c}\text { Survival } \\
\text { rate at } \\
9 \text { weeks } \\
(\%)\end{array}$ & $\begin{array}{c}\text { Females } \\
\text { killed }\end{array}$ & $\begin{array}{c}\text { Fetal } \\
\text { death and } \\
\text { expulsion } \\
(\%)\end{array}$ \\
\hline Controls & 2 & 9 & $\begin{array}{r}23.0 \\
\pm 0.2\end{array}$ & $\begin{array}{r}13.9 \\
\pm 1.3\end{array}$ & 124 & 1 & 90 & 0 & - \\
\hline RU 2858 & & & & & & & & & \\
\hline 0.4 & 2 & 5 & $\begin{array}{r}22.8 \\
\pm 0.2\end{array}$ & $\begin{array}{r}12.6 \\
\pm 1.3\end{array}$ & 63 & 0 & 95 & 0 & - \\
\hline 2 & $32 * *$ & 12 & $\begin{array}{r}22.9 \\
\pm 0.2\end{array}$ & $\begin{array}{r}12.3 \\
\pm 1.1\end{array}$ & 147 & 1 & 95 & 0 & - \\
\hline 10 & $59^{* *}$ & 9 & $\begin{array}{r}22.6 \\
\pm 0.2\end{array}$ & $\begin{array}{r}12.6 \\
\pm 0.9\end{array}$ & 112 & 1 & 88 & 0 & - \\
\hline 50 & $75^{* *}$ & 11 & $\begin{array}{r}22.6 \\
\pm 0.1\end{array}$ & $\begin{array}{c}9.4 \\
\pm 1.0^{*}\end{array}$ & 91 & 12 & 36 & 2 & 100 \\
\hline Oestradiol & & & & & & & & & \\
\hline 50 & $41^{* *}$ & 7 & $\begin{array}{r}22.3 \\
\pm 0.3\end{array}$ & $\begin{array}{r}11.4 \\
\pm 0.8\end{array}$ & 67 & 13 & 83 & 0 & - \\
\hline 250 & $57^{* *}$ & 4 & $\begin{array}{r}22.3 \\
\pm 0.5\end{array}$ & $\begin{array}{r}11.0 \\
\pm 0.7\end{array}$ & 41 & 3 & 84 & 4 & 100 \\
\hline 1250 & $66^{* *}$ & 9 & $\begin{array}{l}22.2^{*} \\
\pm 0.2\end{array}$ & $\begin{array}{c}4 \cdot 7 \\
\pm 1 \cdot 1^{* *}\end{array}$ & 22 & 20 & 33 & 12 & 100 \\
\hline
\end{tabular}

Significantly different from control value: $* P<0.05, * * P<0.01$ (Dunnett's test).

$\dagger$ Number of resorptions and dead fetuses expressed as a percentage of the total number of implantation sites.

\section{Observations on the males}

Histological examination of the genital tract of male fetuses revealed the following effects of oestrogen treatment (Vannier \& Raynaud, 1975): underdevelopment of Wolffian ducts and of associated organs, total inhibition of prostatic buds and feminization of the genital tubercle (hypospadias), particularly in fetuses from mothers treated with doses of $\geq 10 \mu \mathrm{g}$ RU 2858 and $250 \mu \mathrm{g}$ oestradiol. Lesser effects were observed with doses of $2 \mu \mathrm{g}$ RU 2858 and $50 \mu \mathrm{g}$ oestradiol.

Table 2. Prostate growth in male offspring from mothers treated with oestrogen during gestation (Days 16-20)

\begin{tabular}{|c|c|c|c|c|}
\hline \multirow{2}{*}{$\begin{array}{l}\text { Treatment } \\
\text { (doses) }\end{array}$} & \multicolumn{4}{|c|}{ Length of prostate (mm) } \\
\hline & Day 1 & Day 14 & Day 28 & Day 56 \\
\hline Controls & $0.87 \pm 0.03$ & $5 \cdot 30 \pm \frac{0.23}{(6)}$ & $10 \cdot 10 \pm \frac{0.99}{(4)}$ & $14.00 \pm 0.35$ \\
\hline $\begin{array}{l}\text { RU } 2858 \\
\quad(10 \mu \mathrm{g} / \mathrm{rat} / \text { day })\end{array}$ & $\begin{array}{c}0^{* *} \\
(10)\end{array}$ & $1.72 \pm 0.62^{* *}$ & $5.58 \pm 0.42^{* *}$ & $\begin{array}{c}9.42 \pm 0.85^{*} \\
(9)\end{array}$ \\
\hline $\begin{array}{l}\text { Oestradiol } \\
\quad(250 \mu \mathrm{g} / \mathrm{rat} / \text { day })\end{array}$ & $\begin{array}{c}0.16 \pm 0.04^{* *} \\
(10)\end{array}$ & $3 \cdot 21 \pm 0.27^{* * *}$ & $7.08 \pm 0.49^{*}$ & $\begin{array}{c}10 \cdot 18 \pm 0.57 \\
(10)\end{array}$ \\
\hline
\end{tabular}

Values are mean \pm s.e.m. for the no. of animals in parentheses.

Significantly different from control values: ${ }^{*} P<0.05{ }^{* *} P<0.01$ (Dunnett's test). 
Examination of serial transverse sections of the urogenital sinus of the young revealed that post-natal formation of the prostate gland was similar after RU 2858 and oestradiol treatment (Table 2). Some rudimentary glands (anlagen) were observed in the dorsal and lateral regions after 2 weeks, becoming more substantial after 4 weeks and reaching a sufficient size after 8 weeks to be potentially functional. However the ventral buds remained underdeveloped.

At adulthood, abnormalities of the associated organs were observed in the male offspring (Table 3). The prostate was underdeveloped in a dose-dependent fashion: inhibition was only partial in most of the animals from mothers given $10 \mu \mathrm{g} \mathrm{RU} 2858$, but total in two-thirds of the males in the $50 \mu \mathrm{g}$ RU 2858 group and in all the males in the $1250 \mu \mathrm{g}$ oestradiol group. Seminal vesicles were also inhibited in the highest dose groups. The penis was hypospadic in the majority of animals and the testes were cryptorchid in some animals of the highest-dose groups. When the adult male offspring were mated with untreated females, the mating and fecundity rates were normal for this strain except in the highest-dose groups, i.e. the fecundity rate was very low in the $50 \mu \mathrm{g}$ RU 2858 group and sterility was complete in the $1250 \mu \mathrm{g}$ oestradiol group.

Table 3. Observations on adult male offspring from mothers treated with oestrogen during gestation (Days 16-20)

\begin{tabular}{|c|c|c|c|c|c|c|c|c|c|c|}
\hline \multirow{4}{*}{$\begin{array}{l}\text { Treatment } \\
\text { and doses } \\
(\mu \mathrm{g} / \mathrm{rat} / \mathrm{day})\end{array}$} & \multirow{4}{*}{$\begin{array}{c}\text { No. } \\
\text { of } \\
\text { rats }\end{array}$} & \multicolumn{6}{|c|}{ Morphological changes } & \multirow{2}{*}{\multicolumn{3}{|c|}{ Reproductive function }} \\
\hline & & \multirow{2}{*}{\multicolumn{2}{|c|}{$\begin{array}{c}\text { Prostate } \\
\text { inhibition }\end{array}$}} & \multirow{2}{*}{\multicolumn{2}{|c|}{$\begin{array}{l}\text { Seminal vesicle } \\
\text { inhibition }\end{array}$}} & \multirow[b]{3}{*}{ Hypospadias } & \multirow[b]{3}{*}{ Cryptorchid } & & & \\
\hline & & & & & & & & \multirow{2}{*}{$\begin{array}{l}\text { No. } \\
\text { of } \\
\text { rats }\end{array}$} & \multirow{2}{*}{$\begin{array}{l}\text { Mating } \\
\text { rate } \\
(\%)\end{array}$} & \multirow{2}{*}{$\begin{array}{c}\text { Fecundity } \\
\text { rate } \\
(\%)\end{array}$} \\
\hline & & Partial* & Total & Partial & Total & & & & & \\
\hline \multicolumn{10}{|l|}{ RU 2858} & 97 \\
\hline 0.4 & 25 & 0 & 0 & 0 & 0 & 0 & 0 & 23 & 95 & 84 \\
\hline 2 & 30 & 1 & 0 & 0 & 0 & 0 & 1 & 35 & 85 & 88 \\
\hline 10 & 40 & 29 & 0 & 0 & 0 & 0 & 5 & 30 & 93 & 91 \\
\hline 50 & 24 & 8 & 16 & 13 & 3 & 22 & 8 & 24 & 25 & 8 \\
\hline \multicolumn{11}{|l|}{ Oestradiol } \\
\hline 50 & 25 & 0 & 0 & 0 & 0 & 0 & 0 & 20 & 90 & 100 \\
\hline 250 & 15 & 6 & 0 & 0 & 0 & 0 & 1 & 19 & 89 & 86 \\
\hline 1250 & 6 & 0 & 6 & 3 & 0 & 6 & 6 & 6 & 0 & 0 \\
\hline
\end{tabular}

* When inhibition was partial, the underdevelopment of the ventral lobes was no more marked than that of the dorsal or lateral lobes.

\section{Observations on the females}

In the female fetuses from mothers given $50 \mu \mathrm{g}$ RU 2858 or, to a lesser extent, $250 \mu \mathrm{g}$ oestradiol, the changes in the genital tract consisted of dilatation of the uterus, inhibition of the lower part of the vagina which was bifid in 3 fetuses and partial to complete persistence of Wolffian ducts (Gartner's ducts).

At adulthood, external abnormalities were observed in the female offspring (Table 4). In most cases the clitorine urethra was cleft to an extent depending upon dose. In offspring from the $2 \mu \mathrm{g}$ RU 2858 or $250 \mu \mathrm{g}$ oestradiol groups a small opening was located at the caudal base of the cleft phallus; histological examination revealed that the urethra and vagina had a common orifice but no internal junction. In offspring from mothers treated with higher doses, a well developed vagina was lacking and an internal vaginal-urethral junction was observed. In the high dosage groups, the ovaries were small with no corpora lutea. Moreover, persistence of Wolffian ducts was noted in 2 females from the $1250 \mu \mathrm{g}$ oestradiol group. In adult female offspring from mothers treated with $0.4 \mu \mathrm{g} \mathrm{RU} 2858$ or $250 \mu \mathrm{g}$ oestradiol the mating and fecundity rates were comparable to those of the control group and fertility was only slightly reduced. In all other 
groups, oestrogen treatment induced a dose-dependent decrease in these values. Reproductive function was very poor with $10 \mu \mathrm{g}$ RU 2858 and abolished with the highest dose of both compounds. No vaginal spermatozoa were detected and the animals remained in permanent oestrus.

Table 4. Observations on adult female offspring from mothers treated with oestrogen during gestation (Days 16-20)

\begin{tabular}{|c|c|c|c|c|c|c|c|c|c|}
\hline \multirow{4}{*}{$\begin{array}{l}\text { Treatment } \\
\text { and dose } \\
(\mu \mathrm{g} / \mathrm{rat} / \mathrm{day})\end{array}$} & \multirow{2}{*}{\multicolumn{4}{|c|}{ Morphological changes }} & \multicolumn{5}{|c|}{ Reproductive function } \\
\hline & & & & & \multirow{3}{*}{$\begin{array}{l}\text { No. } \\
\text { of } \\
\text { rats }\end{array}$} & \multirow{3}{*}{$\begin{array}{c}\text { Permanent } \\
\text { oestrus } \\
(\%)\end{array}$} & \multirow{3}{*}{$\begin{array}{l}\text { Mating } \\
\text { rate } \\
(\%)\end{array}$} & \multirow{3}{*}{$\begin{array}{c}\text { Fecundity } \\
\text { rate } \\
(\%)\end{array}$} & \multirow{3}{*}{$\begin{array}{c}\text { Mean } \pm \text { s.e.m. } \\
\text { no. of } \\
\text { implantation } \\
\text { sites } / \text { rat }\end{array}$} \\
\hline & \multirow{2}{*}{$\begin{array}{l}\text { No. } \\
\text { of } \\
\text { rats }\end{array}$} & \multicolumn{2}{|c|}{ Hypospadias } & \multirow{2}{*}{$\begin{array}{l}\text { Vaginal- } \\
\text { urethral } \\
\text { junction }\end{array}$} & & & & & \\
\hline & & Slight & Marked & & & & & & \\
\hline Controls & 30 & 0 & 0 & 0 & 40 & 0 & 72 & 75 & $\begin{array}{r}12.5 \\
\pm 0.9\end{array}$ \\
\hline \multicolumn{10}{|l|}{ RU 2858} \\
\hline 0.4 & 24 & 18 & 0 & 0 & 24 & 0 & 79 & 84 & $\begin{array}{c}9.3 \\
\pm 1.0^{*}\end{array}$ \\
\hline 2 & 40 & 35 & 5 & 0 & 61 & 40 & 59 & 58 & $\begin{array}{c}3.6 \\
\pm 0.6^{*}\end{array}$ \\
\hline 10 & 50 & 0 & 40 & 5 & 33 & 96 & 12 & 25 & 1.0 \\
\hline 50 & 18 & 0 & 18 & 18 & 24 & 100 & 0 & 0 & 0 \\
\hline \multicolumn{10}{|l|}{ Oestradiol } \\
\hline 50 & 30 & 0 & 0 & 0 & 30 & 0 & 70 & 85 & $\begin{array}{r}11.6 \\
\pm 0.6\end{array}$ \\
\hline 250 & 18 & 0 & 1 & 0 & 18 & 0 & 72 & 100 & $\begin{array}{c}7.2 \\
\pm 1.4^{*}\end{array}$ \\
\hline 1250 & 10 & 0 & 10 & 10 & 10 & 100 & 0 & 0 & 0 \\
\hline
\end{tabular}

* Significantly different from control value, $P<0.01$ (Dunnett's test).

\section{Discussion}

The morphological changes observed in this study on the genital tract of rat fetuses from oestrogen-treated mothers confirm observations by Marois (1968) in rats and by Raynaud (1942) and Jean (1968) in mice. As reported by Falconi \& Rossi (1965), the oestradiol doses that induced these changes were very close to embryotoxic doses. RU 2858 gave rise to all the effects induced by oestradiol, at lower doses, except for one. The paradoxical retention of the Wolffian ducts observed with high oestrauiol doses previously recorded by Greene, Burrill \& Ivy (1939) and still unexplained (Stinnakre, 1972), was not noted with RU 2858. It could be argued that this retention might result from oestradiol interaction with androgen receptors. Should this be the case, the inactivity of RU 2858 is not surprising since this compound does not compete for binding to the androgen receptor even at high concentrations (Ojasoo \& Raynaud, 1978).

This study was also designed to evaluate the fate of the morphological changes of the genital tract under oestrogen treatment and revealed a tendency towards their reversal during maturity which was related to dose and sex. Thus, in male offspring from mothers treated with $10 \mu \mathrm{g} \mathrm{R}$ 2858 or $250 \mu \mathrm{g}$ oestradiol from Days 16 to 20 of gestation, inhibition of the Wolffian ducts was removed and prostate growth was restored from the 2 nd week of postnatal life and the penis was normal. However, after treatment with higher doses (50 $\mathrm{g}$ RU 2858 and $1250 \mu \mathrm{g}$ oestradiol), anomalies such as cryptorchidism and testicular atrophy were still present at puberty as previously reported (Greene et al., 1940), and the observed underdevelopment of the gonads lessened (in the case of unilateral ectopy) or totally impeded the chances of fecund coitus.

Sensitivity to oestrogen was greater in the female offspring and morphological and functional changes were apparent in adults from mothers treated with $10 \mu \mathrm{g} R \mathrm{RU} 2858$, i.e. high 
frequency of hypospadias, induction of permanent oestrus, reduced fecundity and fertility rates. On the basis of these criteria, the RU 2858: oestradiol activity ratio was about 100 . The high potency of RU 2858 can be explained by the fact that, unlike oestradiol, it does not bind specifically to oestradiol-binding protein in the plasma of neonatal rats (Raynaud, 1973) and that it forms a more slowly dissociating complex with the cytoplasmic oestrogen receptor (Bouton \& Raynaud, 1979). The $\alpha$-methoxy isomer of RU 2858, i.e. RU 16117, which does not bind to oestradiol-binding protein and differs from RU 2858 by its rapid dissociation rate only, was less active than RU 2858, a dose of $20 \mu$ g causing only mild effects (unpublished data).

The morphological and functional changes induced in the offspring by treatment of mothers with high doses of oestrogen and leading at times to sterility are similar to those induced by postnatal oestrogen treatment of the male (Levine \& Mullins, 1964; Soulairac \& Soulairac, 1974; Brown-Grant et al., 1975) and female (Gorski, 1963; Whalen \& Nadler, 1963; Doughty et al., 1975) in terms of receptivity and lordosis behaviour and could be explained by some irreversible change in the brain during prenatal sexual differentiation. The known effects of postnatal oestrogen treatment on subsequent responsiveness have been related, at least in part, to the presence of functional oestrogen receptors in brain structures during the critical period of sexual differentiation of the brain. In the rat brain, specific oestrogen binding has been detected about 3-7 days after birth (Kato, Atsumi \& Inaba, 1974; Barley, Ginsburg, Greenstein, MacLusky \& Thomas, 1974; McEwen, Pfaff, Chaptal \& Luine, 1975), on the day of birth (Raynaud \& Moguilewsky, 1977) and on Day 21 of gestation (MacLusky, Lieberburg \& McEwen, 1979). Oestrogen receptors have previously been detected in the embryonic brains of the guinea-pig (Pasqualini \& Palmada, 1972; Plapinger, Landau, McEwen \& Feder, 1977), man (Davies, Naftolin, Ryan \& Siu, 1975) and mouse (Vito \& Fox, 1979). The prenatal sensitivity of rats to oestrogen, reported in this paper, suggests that, in the absence of a postnatal action due to oestrogen remaining in the circulation after birth, these putative oestrogen receptors in the rat embryonic brain might be functional and responsible for the observed effects.

We thank M. Bénicourt, R. Brémaud and P. Julien for their competent technical assistance.

\section{References}

Barley, J., Ginsburg, M., Greenstein, B.D., MacLusky, N.J. \& Thomas, P.J. (1974) A receptor mediating sexual differentiation? Nature, Lond. 252, 259-260.

Barraclough, C.A. (1968) Alterations in reproductive function following prenatal and early postnatal exposure to hormones. Adv. Reprod. Physiol. 3, 81112.

Bouton, M.M. \& Raynaud, J.P. (1979) The relevance of interaction kinetics in determining biological response. Endocrinology 105, 509-515.

Brown-Grant, K. (1974) On 'critical periods' during the post-natal development of the rat. In L'Endocrinologie Sexuelle de la Période Périnatale, pp. 357-376. INSERM (Vol. 32), Paris.

Brown-Grant, K., Fink, G., Greig, F. \& Murray, M.A.F. (1975) Altered sexual development in male rats after oestrogen administration during the neonatal period. J. Reprod. Fert. 44, 25-42.

Davies, I.J., Naftolin, F., Ryan, K.J. \& Siu, J. (1975) A specific, high-affinity, limited-capacity estrogen binding component in the cytosol of human fetal pituitary and brain tissues. J. clin. Endocr. Metab. 40, 909912.
Domer, G., Docke, F. \& Hinz, G. (1971) Paradoxical effects of estrogen on brain differentiation. Neuroendocrinology 7, 146-155.

Doughty, C., Booth, J.E., McDonald, P.G. \& Parrott, R.F. (1975) Effects of oestradiol-17 $\beta$, oestradiol benzoate and the synthetic oestrogen RU 2858 on sexual differentiation in the neonatal female rat. $J$. Endocr. 67, $419-424$.

Falconi, G. \& Rossi, G.L. (1965) Some effects of oestradiol 3-benzoate on the rat foetus. Proc. Eur. Soc. for Study Drug Tox. 6, 150-156.

Gorski, R.A. (1963) Modification of ovulatory mechanisms by postnatal administration of estrogen to the rat. Am. J. Physiol. 205, 842-844.

Greene, R.R., Burrill, M.W. \& Ivy, A.C. (1939) The paradoxical effects of oestrogens on the sexual development of the female rat. Anat. Rec. 74, 429438.

Greene, R.R., Burrill, M.W. \& Ivy, A.C. (1940) Experimental intersexuality: The effects of estrogens on the antenatal sexual development of the rat. Am. J. Anat. 67, 305-345.

Harris, G.W. \& Levine, S. (1965) Sexual differentiation 
of the brain and its experimental control. J. Physiol. Lond. 181, 379-400.

Hendricks, S.E. \& Weltin, M. (1976) Effect of estrogen given during various periods of prepubertal life on sexual behavior of rats. Physiol. Psychol. 4, 105-110.

Jean, C. (1968) Malformations génitales induites chez la souris adulte par une action oestrogène prénatale. II. La femelle. Archs Anat. microsc. Morph. exp. 57, 191-226.

Kato, J., Atsumi, Y. \& Inaba, M. (1974) Estradiol receptors in female rat hypothalamus in the developmental stages and during pubescence. Endocrinology 94, 309-317.

Levine, S. \& Mullins, R. (1964) Estrogen administered neonatally affects adult sexual behavior in male and female rats. Science, N.Y. 144, 185-187.

MacLusky, N.J., Lieberburg, I. \& McEwen, B.S. (1979) The development of estrogen receptor systems in the rat brain: gestational appearance and perinatal development. Brain Res. 178, 129-142.

Marois, G. (1968) Action de la progestérone, de la testostérone et de l'oestradiol sur la distance anogénitale et sur la différenciation sexuelle somatique du rat. Biol. Med. 57, 44-90.

McEwen, B.S., Pfaff, D.W., Chaptal, C. \& Luine, V.N. (1975) Brain cell nuclear retention of $(3 \mathrm{H})$ estradiol doses able to promote lordosis: temporal and regional aspects. Brain Res. 86, 155-161.

Ojasoo, T. \& Raynaud, J.P. (1978) Unique steroid congeners for receptor studies. Cancer Res. 38, 41864198.

Pasqualini, J.R. \& Palmada, M. (1972) Biochimie endocrinienne: étude du récepteur de l'oestradiol-17 $\beta$ dans le cerveau du foetus de cobaye. $C$. $r$. hebd. Séanc. Acad. Sci., Paris D 274, 1218-1221.

Passouant-Fontaine, T. \& Flandre, C. (1969) Effets à long terme des oestrogènes injectés à la période néonatale chez le Rat. J. Physiol., Paris 61, 423-434.
Plapinger, L., Landau, I.T., McEwen, B.S. \& Feder, H.H. (1977) Characteristics of estradiol-binding macromolecules in fetal and adult guinea pig brain cytosols. Biol. Reprod. 16, 586-599.

Raynaud, A. (1942) In Modification Expérimentale de la Différenciation Sexuelle des Embryons de Souris par Action des Hormones Androgènes et Oestrogènes, pp. 66-134. Hermann \& Cie, Paris.

Raynaud, J.P. (1973) Influence of rat estradiol binding plasma protein (EBP) on uterotrophic activity. Steroids 21, 249-258.

Raynaud, J.P., Bouton, M.M., Philibert, D. \& Vannier, B. (1976) Steroid binding in the hypothalamus and pituitary. In Hypothalamus and Endocrine Functions, pp. 171-189. Eds F. Labrie, J. Meites \& G. Pelletier. Plenum Press, New York.

Raynaud, J.P. \& Moguilewsky, M. (1977) Steroid competition for estrogen receptors in the central nervous system. In Clinical Reproductive Neuroendocrinology, pp. 78-87. Eds P. O. Hubinont, M. L'Hermite \& C. Robyn. Karger, Basel.

Soulairac, M.L. \& Soulairac, A. (1974) Conséquences de l'estrogenisation post-natale sur le comportement sexuel et le tractus génital du rat mâle adulte. $J$. Physiol., Paris, 68, 19B-20B.

Stinnakre, M.G. (1972) Etude de l'action "paradoxale" des estrogènes sur les canaux de Wolff des foetus femelles de Rat, l'aide d'un anti-androgène l'acétate de "cyprotérone". C. r. hebd. Séanc. Acad. Sci., Paris $D$ 275, 101-103.

Vannier, B. \& Raynaud, J.P. (1975) Effect of estrogen plasma binding on sexual differentiation of the rat fetus. Mol. cell. Endocr. 3, 323-337.

Vito, C.C. \& Fox, T.O. (1979) Embryonic rodent brain contains estrogen receptors. Science, N.Y. 204, 517519.

Whalen, R.E. \& Nadler, R.D. (1963) Suppression of the development of female mating behavior by estrogen administered in infancy. Science, N.Y. 141, 273-274.

Received 16 August 1979 